\title{
PENGARUH BRAND IMAGE GOJEK TERHADAP LOYALITAS KONSUMEN (STUDI KASUS EFEK COVID-19 KONSUMEN KARAWACI TEGAL BARU TANGERANG)
}

\author{
Andres Dharma Nurhalim \\ Sekolah Tinggi Ilmu Ekonomi Wiyatamandala \\ andres@wym.ac.id
}

\begin{abstract}
COVID-19 caused many significant impacts on various businesses in Indonesia. This outbreak was first announced by the government in early March in 2020 and as a result online transportation companies also have the impact of a decrease in services due to the outbreak. This study aims to determine the effect of brand image gojek on consumer loyalty when the covid 19 effect takes place. The analytical method used by the author in conducting this research is to use quantitative research with a population of 150 respondents which is a community that lives in Karawaci, Tangerang. In carrying out the data collection is done by distributing questionnaires in which there are several items of statement. in this study the variables are divided into several parts including Brand Image $(X)$ and Consumer Loyalty $(Y)$ as the dependent variable. To measure the magnitude of the effect on these variables, the authors use the linear regression analysis method. From the results of the analysis it was found that there is a significant and simultaneous influence on the brand image of the object of consumer loyalty.
\end{abstract}

Keywords: Brand Image, Loyalitas Konsumen, Covid-19

\section{PENDAHULUAN}

Kemajuan teknologi adalah suatu hal yang tidak dapat dihindari dalam peradaban kehidupan manusia. Teknologi itu sendiri hingga saat ini terus berjalan seiring dengan perkembangan zaman. Perkembangan di dalam bidang teknologi ini tentu sangat diperlukan oleh manusia karena dapat membantu banyak hal dalam keberlangsungan hidup manusia itu sendiri. Seiring dengan perjalanan waktu pun teknologi terus menghadirkan inovasi-inovasi menarik dan juga membawa dampak besar kepada manusia baik dalam hal positif maupun negatif. Adanya inovasi dalam perkembangan teknologi pun sangat perlu untuk terus dikembangkan dan dihadirkan agar dapat memberikan dampak yang lebih berpengaruh serta bermanfaat dalam kehidupan manusia itu sendiri. Dewasa ini perkembangan teknologi semakin maju dan terus berkembang sangat pesat. Teknologi pun dengan mudahnya dapat diakses 
oleh masyarakat kapanpun dan di manapun melalui gadget mereka. Tak hanya dalam perkembangan teknologi yang mempermudah komunikasi terhadap sesama, tetapi dalam hal lainnya seperti mempermudah pekerjaan manusia. Menurut hasil survei yang dilakukan oleh statista data (2019) menunjukkan pengguna internet di Indonesia pada 2018 sebanyak 95,2 juta, tumbuh 13,3\% dari 2017 yang sebanyak 84 juta pengguna. Pada tahun selanjutnya pengguna internet di Indonesia akan semakin meningkat dengan rata-rata pertumbuhan sebesar $10,2 \%$ pada periode 2018-2023. Pada 2019 jumlah pengguna internet di Indonesia diproyeksikan tumbuh $12,6 \%$ dibandingkan 2018, yaitu menjadi 107,2 juta pengguna. Inovasi terus menerus bermunculan dalam kehidupan masyarakat. Inovasi yang saat ini begitu digemari oleh masyarakat Indonesia yaitu adanya aplikasi transportasi online. Tidak hanya sekedar digemari, transportasi online pun telah membawa dampak yang cukup besar bagi kehidupan masyarakat. Aplikasi transportasi online ini adalah salah satu bentuk nyata bahwa teknologi dapat dinikmati oleh semua kalangan masyarakat di Indonesia. Salah satu perusahaan dari Indonesia yang menyediakan jasa pelayanan transportasi online yaitu PT Gojek Indonesia. Kehadiran Gojek langsung disambut baik oleh masyarakat Indonesia. Aplikasi Gojek dengan mudahnya dapat diakses dari gadget masyarakat kapanpun dan dimanapun selama terhubung dengan koneksi internet. PT Gojek sendiri terus mengembangkan berbagai macam layanan dalam aplikasinya yang dapat mempermudah kehidupan masyarakat Indonesia pada saat ini. Berbagai macam layanan Gojek tersebut tidak hanya berupa jasa transportasi melainkan adanya jasa lain yang dapat digunakan untuk mempermudah kegiatan masyarakat sehari-hari. Jasa Gojek pun semakin lama semakin tumbuh menjadi bagian dari kegiatan dan gaya hidup masyarakat yang tak dapat dihindari kehadirannnya saat ini. Namun di awal tahun 2020, muncul Wabah yang berasal dari kota Wuhan, China, di mana penyakit tersebut di namakan covid-19 atau korona. yang menyebabkan gangguan pernapasan akut pada manusia. Dari wabah tersebut banyak negara 
memutuskan untuk melakukan lockdown untuk memutuskan mata rantai penyebaran virus covid-19. Tepatnya di awal maret 2020, pemerintah mengumumkan bahwa ada kasus masyarakat indonesia positif covid-19, tentu saja dari dampak wabah tersebut perusahaan transportasi online khususnya gojek memiliki dampak yang negatif. Perusahaan transportasi online terkena imbas penyebaran corona (covid-19) karena pemerintah menerapkan kebijakan kerja dari rumah (Work From Home/WFH) dan pembatasan sosial berskala besar (PSBB). Bagaimana kondisi perusahaan transportasi online setelah kebijakan WFH berjalan? Menurut lembaga Statqo Analytics yang mengkaji kondisi dua perusahaan transportasi online yaitu Grab dan Gojek, pengguna aktif transportasi online mengalami penurunan sejak pertengahan Maret 2020 lalu. Tepatnya setelah pemberlakuan imbauan work from home (WFH) sebagai upaya mencegah penyebaran virus corona. Menurut analisis lembaga tersebut sejak 13 Maret 2020, pengguna Gojek dan Grab kompak mengalami penurunan jumlah pengguna aktif secara harian. "Rata-rata jumlah pengguna harian kedua moda transportasi itu diperkirakan menurun hingga $17 \%$ selama 1 bulan terakhir," kata Adzkia. Berdasarkan Data Statqo rata-rata pengguna aktif pada aplikasi Gojek pada akhir Februari 2020 berada di kisaran 3,3 juta pengguna. Akan tetapi memasuki bulan Maret 2020 mulai terjadi penurunan. Pengguna aktif Gojek menurun sekitar $14 \%$ dari ratarata mingguan pada 13 Maret sekitar 3,2 juta pengguna, menjadi hanya 2,5 juta pengguna pada 26 Maret 2020. Data ini juga menunjukkan penurunan pada minggu kedua bulan Maret yakni pada tanggal 19 Maret, Gojek turun di angka 2,9 juta sedangkan Grab hanya 2,4 juta. Untuk itu, dengan adanya dampak negatif virus corona terhadap industri transportasi online ini harus segera diantisipasi oleh pemerintah. Dari informasi yang penulis dapat di tanggal 1 april 2020 bahwa penyebaran covid19 terkonfirmasi covid-19 sebanyak 1.677 positif covid-19, sembuh sebanyak 103 dan meninggal sebanyak 157 orang. Dari penyebaran virus tersebut Gojek perlu menguatkan upayanya membantu para mitra driver untuk memastikan keberlangsungan mata pencaharian mereka di tengah penurunan aktivitas masyarakat agar brand image tetap kuat dan dapat 
diterima secara positif oleh konsumen. Terjadinya covid-19 yang berada di indonesia, ketika sebuah merek memiliki citra yang kuat dan positif di benak konsumen maka merek tersebut akan selalu diingat dan kemungkinan konsumen untuk membeli merek yang bersangkutan sangat besar pada gojek yang nantinya berpengaruh kepada loyalitas pelanggan. Terkait data yang diperoleh membuktikan bahwa baik pengguna maupun pelaku bisnis

\section{TINJAUAN PUSTAKA}

Brand

Keller (1991) mengatakan bahwa merek merupakan nama, istilah, tanda, simbol, atau desain atau kombinasi dari mereka yang dimaksudkan untuk mengidentifikasi barang dan jasa dari satu penjual atau kelompok penjual dan untuk membedakan mereka dari barangbarang pesaing. Dengan demikian, merek memberikan sinyal kepada pelanggan sumber produk, dan melindungi pelanggan dan pelanggan produsen dari pesaing yang akan berusaha menyediakan produk yang tampaknya identik. transportasi online kena imbas corona sehingga masyarakat konsumen di tangerang karawaci tegal baru dipilih untuk dijadikan populasi pada penelitian ini agar memudahkan penulis dalam melakukan penelitian. Rumusan masalah yang akan diteliti lebih lanjut dalam penelitian ini yaitu seberapa besar hubungan antara brand image Gojek dengan loyalitas konsumen efek covid-19 pada konsumen karawaci tegal baru tangerang?

Kotler dan keller (2016) mengatakan bahwa merek setidaknya memiliki enam makna yaitu:

1. Attribut

merek dapat memberikan gambaran kepada konsumen mengenai atribut pada merek itu sendiri seperti kualitas yang baik, tahan lama.

2. Manfaat

Manfaat dari merek kemudian harus ditransformasikan dalam bentuk manfaat. Misalnya atribut dengan kualitas yang baik dapat diasumsikan bahwa produk tersebut terbuat dari bahan baku yang baik. 
3. Value

Brand dapat menambah nilai bagi produsen. Misalnya, barang bermerek seperti i-phone selalu khas dengan produk berkualitas baik.

4. Culture

merek mencerminkan budaya tertentu seperti di Jepang yang menghargai efektivitas dan kualitas tinggi.

5. Kepribadian

Merek juga mencerminkan kepribadian dari masing-masing individu. Seorang pria yang mengendarai Ferarri dapat digambarkan sebagai orang yang prestisius dan mewah.

6. User

Brand dapat memberikan gambaran tentang jenis konsumen yang membeli atau menggunakan produk. Ferrari cocok untuk mereka yang sudah stabil dalam hal keuangan dan usia.

Ekuitas Merek

Ekuitas merek adalah citra dari produk termasuk bagaimana produk itu dapat dirasakan (sporty, mewah, teknologi tinggi) dan perasaan yang sesuai dengan citra dari pelanggan. Aaker (1991) mengklasifikasikan ekuitas merek menjadi lima elemen sebagai berikut:

1. Kesadaran merek.

Menunjukkan kemampuan pembeli untuk mengenali atau mengingat kembali produk.

2. Asosiasi merek,

mencerminkan citra merek terhadap kesan tertentu dalam kaitannya dengan kebiasaan, gaya hidup, manfaat, atribut produk, harga.

3. Kualitas yang Dipersepsikan Kualitas yang dipersepsikan menunjukkan persepsi konsumen tentang kualitas dan keunggulan produk.

4. Loyalitas merek.

Loyalitas merek mewakili tingkat minat konsumen terhadap merek.

5. Aset merek eksklusif lainnya, Ini melibatkan hak cipta, teknologi, rahasia bisnis, akses khusus ke pemasok

Citra Merek

Citra Merek adalah representasi dari semua persepsi terhadap merek dan dibangun dari informasi dan 
pengalaman masa lalu. Gambar dari mereknya terhubung dengan perilaku seperti kepercayaan dan preferensi pada merek tertentu. Konsumen yang memiliki citra positif terhadap merek tertentu kemungkinan akan membelinya (Setiadi, 2003). Merek tersebut dapat menyampaikan pesan positif atau negatif tentang produk tersebut kepada konsumen. Aaker mengemukakan citra merek adalah serangkaian asosiasi dari konsumen terhadap merek dan biasanya disusun dalam suatu makna. Hubungan pada merek akan semakin kuat jika didasarkan pada pengalaman masa lalu dan informasi dari orang lain. Citra yang positif dan terkenal adalah aset bagi semua perusahaan karena citra tersebut merupakan influencer pembelian yang kuat yang memengaruhi persepsi konsumen tentang perusahaan dan komunikasinya. Ketika konsumen menciptakan harapan dan mengalami kualitas teknis dan fungsional, kualitas yang berpengalaman dapat mengubah gambar. Jika kualitas yang dialami setara dengan gambar, gambar akan diperkuat atau ditingkatkan. Tetapi jika perusahaan tidak berhasil memberikan gambar yang berpengalaman efeknya akan menjadi kebalikannya. Davis (2000) menyatakan bahwa citra merek memiliki dua elemen sebagai berikut:

1. Asosiasi Merek

Asosiasi merek adalah segala sesuatu yang terkait dalam memori dengan suatu merek. Asosiasi menyediakan fakta bahwa produk digunakan untuk mengekspresikan gaya hidup sementara asosiasi lain mencerminkan posisi sosial, dan peran profesional. Kemudian yang lain akan mencerminkan asosiasi yang melibatkan aplikasi produk, tipe orang yang mungkin menggunakan produk, toko yang membawa produk, atau tenaga penjualan yang menangani produk. Asosiasi merek sebagai simpul informasi yang dihubungkan dengan simpul merek dalam memori yang mengandung makna konsumen merek. Asosiasi ini melibatkan persepsi kualitas merek dan sikap terhadap merek.

2. Kepribadian Merek

Kepribadian merek dapat membantu mengkomunikasikan atribut produk dan dengan demikian berkontribusi pada 
manfaat fungsional. Demikian pula, ini dapat membantu menciptakan manfaat ekspresif diri yang menjadi kendaraan bagi pelanggan untuk mengekspresikan kepribadiannya sendiri.

Loyalitas dapat diukur dengan item sikap dan perilaku. Pengukuran sikap, karena fakta bahwa mereka mencerminkan keterikatan psikologis dan emosional terhadap kesetiaan, digunakan untuk memahami elemen kognitif yang mendasari motif pembelian dan tindakan di masa depan. Mereka dipandang untuk menambahkan beberapa tingkat nilai pada produk atau layanan (Wu, 2011). Vesel dan Zabkar 2009 mengatakan bahwa pengukuran perilaku, di sisi lain, fokus pada sejarah pembelian pelanggan dan telah diukur oleh perilaku pembelian berulang yang ditunjukkan oleh pelanggan terhadap suatu produk atau layanan (Wu , 2011). Pelanggan juga dapat membedakan antara loyalitas aktif dan loyalitas pasif. Loyalitas aktif mengacu pada iklan dari mulut ke mulut dan niat pelanggan untuk menggunakan suatu produk atau layanan, sedangkan loyalitas pasif melibatkan keputusan pelanggan untuk tetap bersama perusahaan bahkan ketika dia tidak sepenuhnya puas dengan produk. atau layanan yang diberikan Barnes (2000) menjelaskan dalam Rahasia Manajemen Hubungan Pelanggan bahwa kesetiaan dapat dicapai dengan menerapkan 4R yaitu:

1. Perhatian: itu termasuk memenuhi kebutuhan konsumen, memberikan nilai tambah, menyediakan harapan masa depan untuk konsumen

2. Hubungan: tahap ini membutuhkan upaya yang lebih besar dari perusahaan, seperti memberikan perhatian pribadi kepada konsumen dengan melakukan kontak rutin, mengucapkan selamat ulang tahun, memberikan klien informasi tentang iklim investasi terbaru.

3. Referensi: pada tahap ini, konsumen dalam hal ini adalah klien yang memberikan word of mouth (WOM) positif dan merekomendasikan produk atau layanan kepada orang lain

4. Pemulihan: perusahaan menyiapkan prosedur pencegahan jika ada kegagalan dalam proses konsumsi layanan yang menyebabkan konsumen 
kecewa, sehingga konsumen tidak akan lakukan WOM negatif, mereka bahkan dapat dipeluk lagi sebagai konsumen.

Ovelock (2011) berpendapat bahwa membangun loyalitas konsumen tidak mudah, roda loyalitas dapat menjadi alat yang membantu untuk membangun loyalitas konsumen. Ada 3 tahap strategi dalam roda loyalitas:

1. Membangun fondasi untuk loyalitas dengan segmentasi, dan menentukan target yang tepat yang sesuai dengan kompetensi perusahaan.

2. Membuat ikatan loyalitas dengan konsumen, perusahaan harus menciptakan produk atau layanan yang membuat konsumen mau membeli lagi, termasuk program keanggotaan, kegiatan bersama.

3. Mengurangi "pengemudi churn" termasuk menyiapkan prosedur untuk menangani keluhan dan pemulihan yang efektif sehingga konsumen akan tidak memilih pesaing. Ini dapat dilakukan melalui pelatihan karyawan, sistem manajemen hubungan pelanggan

\section{Gambar 1 Wheel of Loyalty}

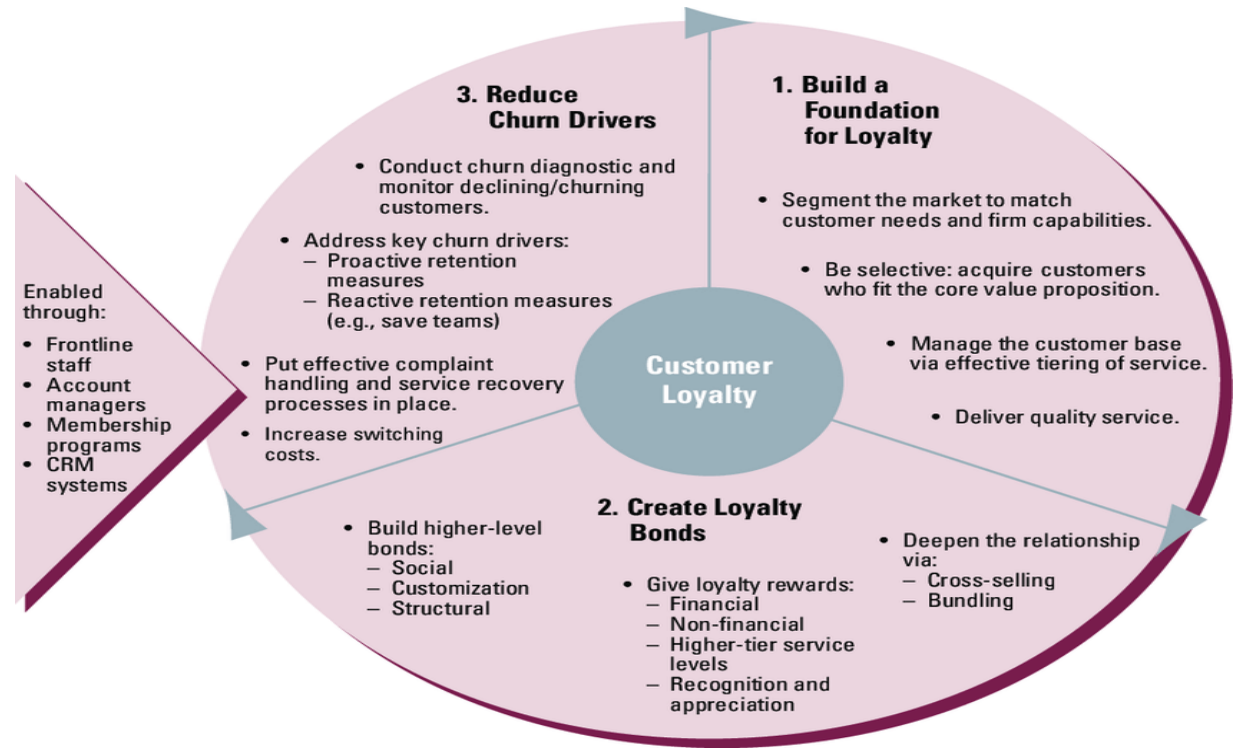

Sumber: Lovelock (2011) 


\section{METODOLOGI PENELITIAN}

Dalam penelitian yang dilakukan ini penelitian menggunakan pendekatan penelitian kuantitatif yang mana merupakan penelitian yang berhubungan dengan angkaangka dan perhitungan. Pendekatan kuantitatif merupakan suatu penelitian yang dilakukan dengan menjelaskan atau membuktikan fenomena atau masalah yang hasilnya dapat digeneralisasikan. (Kriyantono, 2010) Dalam penelitian ini digunakan metode penelitian kuantitatif agar pada hasil penelitian nantinya dapat menunjukan hasil yang akurat dengan perhitungan berupa angka-angka yang telah diperoleh dari hasil perhitungan yang jelas. Dan untuk mengetahui hal tersebut akan dilakukan dengan menggunakan pembagian kuesioner. Kuesioner merupakan salah satu instrumen pengumpulan data yang sering dilakukan dalam penelitian kuantitatif. Pembagian kuesioner kepada responden bertujuan untuk mendapatkan informasi yang dibutuhkan dalam penelitian. Responden yang dimaksud adalah mereka yang memiliki kriteria untuk terlibat dalam populasi yang kemudian diwakili oleh sampel yang diambil dari populasi yang sudah ditentukan sebelumnya dalam penelitian. Populasi yang digunakan dalam penelitian ini yaitu warga tangerang karawaci tegal baru, yang akan digunakan berdasarkan jumlah populasi sejumlah 100. Untuk mendukung penelitian dilakukan teknik lebih lanjut yaitu dengan observasi. Observasi dilakukan langsung dengan melihat kegiatan pengguna Gojek di kawasan lingkungan karawaci-tegal baru sehari-hari. Selanjutnya, teknik pengumpulan data juga dilakukan dengan membaca buku, jurnal, internet, maupun dari berbagai macam sumber lainnya. 


\section{PEMBAHASAN}

Tabel 6 Hasil Model Summary ${ }^{b}$

\begin{tabular}{llrrr} 
Model & $\boldsymbol{R}$ & $\boldsymbol{R}$ Square & $\begin{array}{c}\text { Adjusted } \boldsymbol{R} \\
\text { Square }\end{array}$ & $\begin{array}{l}\text { Std. Error of } \\
\text { the Estimate }\end{array}$ \\
1 & $.614^{\mathrm{a}}$ & .377 & .370 & .36382 \\
\hline
\end{tabular}

a. Predictors: (Constant), Loyalitas_Konsumen

b. Dependent Variable: Brand_Image

Dari tabel diatas dapat dilihat besarnya pengaruh brand image terhadap loyalitas pelanggan Gojek adalah sebesar $37,7 \%$, sisanya sebesar 62,3 $\%$ dipengaruhi oleh variabel lain diluar penelitian ini.

Tabel 7 Hasil Uji ANOVA ${ }^{a}$

\begin{tabular}{rlcrrrr} 
Model & \multicolumn{1}{c}{$\begin{array}{c}\text { Sum of } \\
\text { Squares }\end{array}$} & df & \multicolumn{1}{c}{$\begin{array}{c}\text { Mean } \\
\text { Square }\end{array}$} & F & Sig. \\
\hline 1 & Regression & 1082.302 & 1 & 1082.302 & 94.545 & $.000^{\mathrm{b}}$ \\
& Residual & 1121.858 & 98 & 11.448 & & \\
& Total & 2204.160 & 99 & & &
\end{tabular}

a. Dependent Variable: Loyalitas_Konsumen

b. Predictors: (Constant), Brand Image

Hasil uji anova menunjukkan bahwa nilai signifikan sebesar 0,000 yang berarti model regresi tersebut layak dan cukup baik digunakan untuk memprediksi pengaruh brand image terhadap loyalitas pelanggan Gojek.

Tabel 7 Hasil Coefficients ${ }^{a}$

\begin{tabular}{|c|c|c|c|c|c|}
\hline \multirow[t]{2}{*}{ Model } & \multicolumn{2}{|c|}{$\begin{array}{l}\text { Unstandardized } \\
\text { Coefficients }\end{array}$} & \multirow{2}{*}{$\begin{array}{c}\text { Standardized } \\
\text { Coefficients } \\
\text { Beta }\end{array}$} & \multirow[t]{2}{*}{$T$} & \multirow[t]{2}{*}{ Sig. } \\
\hline & B & Std. Error & & & \\
\hline (Constant) & 1.899 & .224 & & 8.470 & .000 \\
\hline Brand_Image & .476 & .065 & .614 & 7.375 & .000 \\
\hline a. Dependent Variable & litas_kon & umen & & & \\
\hline
\end{tabular}

Dari tabel di atas dapat dilihat bahwa terdapat hubungan signifikan antara brand image dengan loyalitas pengguna Gojek, dari hasil analsisis coeffiecient menunjukkan bahwa nilai signifikan hubungan brand image layanan gojek dengan loyalitas pelanggan Gojek adalah sebesar 0,000 . Hal ini menunjukan bahwa hubungan brand image terhadap loyalitas pengguna 
Gojek $<0,05$ maka dapat disimpulkan terdapat hubungan signifikan antara

\section{SIMPULAN DAN SARAN}

Berdasarkan penelitian yang dilakukan, maka penulis memberikan kesimpulan dan saran yaitu:

1. Brand image Gojek memiliki pengaruh yang signifikan terhadap Loyalitas Konsumen. Hal ini terjadi karena adanya brand image yang baik yang membuat konsumen merasa senang dan juga aman ketika menggunakan jasa yang disediakan oleh perusahaan gojek. Hal ini mempengaruhi kepercayaan konsumen dan mereka dapat menjadi loyal terhadap gojek. Terlaksananya penelitian ini dengan menyebarkan kuesioner yang telah diuji menunjukan adanya pengaruh brand image Gojek terhadap Loyalitas Konsumen.

2. Terdapat hubungan antara brand image terhadap loyalitas konsumen yaitu sebesar pada 0,701 yang mengindikasikan hubungan yang kuat diantara kedua brand image layanan gojek dengan loyalitas pelanggan Gojek.

variabel $\mathrm{X}$ dan $\mathrm{Y}$ tersebut. Hal ini menunjukan bahwa pentingnya mempertahankan dan meningkatkan kualitas dan juga citra merek gojek tersebut.

Adapun saran yang dibuat untuk kedepannya yang dilakukan oleh pihak gojek antara lain:

1. Berbagai inisiatif untuk menjaga kesehatan mitra driver dan konsumen gojek menyadari bahwa mitra driver menjadi andalan saat masyarakat di Indonesia dan di seluruh dunia dihimbau untuk tetap berada dirumah saja untuk memutus mata rantai penularan covid-19. Untuk itu pihak gojek melakukan berbagai macam upaya untuk membantu mitra driver kami tetap sehat dan prima dalam menjalankan kesehariannya. Pihak gojek perlu menyediakan ribuan masker, cairan pembersih (hand sanitizer), vitamin, dan penyemprotan kendaraan dengan cairan desinfektan di berbagai kota besar di Indonesia agar 
mitra driver tetap dalam keadaan sehat dalam kesehariannya. Untuk mitra GoFood wajib menunjukan kartu penanda suhu tubuh hal ini bertujuan untuk memastikan keamanan makanan yang dikirimkan oleh mitra merchant GoFood dan mitra driver. Kartu ini berisi informasi mengenai suhu tubuh dari pihak yang menangani makanan yang dipesan, yaitu karyawan mitra merchant yang memasak, karyawan yang menyiapkan makanan, serta mitra driver yang mengantar makanan.

2. Sosialisasi materi edukasi pedoman kesehatan secara intensif kepada mitra driver untuk melindungi resiko penularan virus edukasi pedoman menjaga kesehatan bagi mitra driver pihak Gojek

\section{DAFTAR PUSTAKA}

Aaker, D.A. 1991, Managing Brand Equity: Capitalizing on The Value of a Brand Name. The Free Press, New York.

Kotler, Philip and Kevin Lane Keller, perlu melakukan sosialisasikan materi edukasi secara berkala terkait pencegahan covid-19 yang mengikuti panduan dari Kementerian Kesehatan Republik Indonesia secara berkala. Pihak gojek dapat menghimbauan untuk konsumen membawa helm sendiri jika memungkinkan, jika tidak membawa helm, konsumen dapat menggunakan hand sanitizer sebelum dan setelah menyentuh helm dari mitra driver. Konsumen juga wajib menggunakan hand sanitzer ketika sebelum maupun menyentuh pintu mobil, wajib menggunakan masker jika konsumen sedang tidak enak badan dan konsumen dihimbau membayar secara non-tunai untuk mengurangi kontak fisik.

2016. Marketing Managemen, 15th Edition. Pearson Education,Inc.

Keller, Kevin Lane. 2013. Strategic Brand Management Global Ed. Boston: Pearson 
Setiadi. 2003. Perilaku Konsumen:

Konsep dan Implikasi Untuk

Strategi Dan Penelitian

Pemasaran. Prenada Media,

Bandung.

Kim, C.K. \& Chung, J. Y. 1997, Brand

Popularity, Country Image and Market Share: An Empirical Study. Journal of International Business Studies, p 61-386.

Davis, S. M. 2000, Brand Asset

Management: Driving Profitable Growth Through Your Brands. John Wiley \& Sons, New York.

Wu, L. W. (2011). Beyond satisfaction: The relative importance of locational convenience, interpersonal relationships, and commitment across service types. Managing Service Quality: An International Journal, 21(3), 240-263

Vesel, P., \& Zabkar, V. (2009).

Managing customer loyalty through the mediating role of satisfaction in the DIY retail loyalty program. Journal of Retailing and consumer Services, 16(5), 396-406.

Lovelock, C., \& Wirtz, J. (2011). Service Marketing: People, Technology, Strategy $\left(7^{\text {th }}\right.$ edition.). Global Edition: Pearson. 